\title{
Distinctive Antigenic Specificities of Adenosine Triphosphatases and Reduced Nicotinamide Adenine Dinucleotide Dehydrogenases as Means for Classification of the Order Mycoplasmatales
}

\author{
KAREN E. SJOSTROM AND GEORGE E. KENNY* \\ Department of Pathobiology, University of Washington School of Public Health and Community Medicine, \\ Seattle, Washington, 98195
}

\begin{abstract}
Since the species classified in order Mycoplasmatales can be separated into at least six antigenically distinct groups by analytical serology, we compared the antigenic specificities of the adenosine triphosphatases (ATPases) and reduced nicotinamide adenine dinucleotide dehydrogenases of 14 strains by using quantitative immunoelectrophoresis and specific strains to identify enzymatically active precipitin peaks. The following species and serological groups were studied: Mycoplasma putrefaciens, Mycoplasma capricolum, and Mycoplasma species bovine group VII (group 1); Acholeplasma laidlawii and Acholeplasma equifetale (group 2); Mycoplasma gallisepticum (group 4); Mycoplasma pneumoniae (group 5); Mycoplasma felis (group 6); Mycoplasma arginini, Mycoplasma hominis, and Mycoplasma gallinarum (group 7); and Ureaplasma urealyticum (ungrouped). Each strain showed ATPase activity which formed a precipitin peak against the homologous antiserum. Eight serologically distinct ATPases were identified, and most of these ATPases cross-reacted only within serologically related clusters of species, not between clusters; the exception was group 7, where the ATPase of $M$. gallinarum had a different specificity than the cross-reacting enzymes of $M$. arginini and $M$. hominis. All species except $U$, urealyticum possessed a reduced nicotinamide adenine dinucleotide dehydrogenase, but the enzymes in $M$. felis, $M$. hominis, and $M$. arginini did not precipitate with any antisera. The remaining species showed five distinct specificities of reduced nicotinamide adenine dinucleotide dehydrogenases, and the antigenic relationships of these enzymes exactly paralleled those observed with ATPases. Thus, the serological specificities of common mycoplasmic enzymes are powerful taxonomic tools.
\end{abstract}

Whereas most procaryotes have cell walls, the members of a small group lack cell walls and are bounded by unit membranes. The membranebound procaryotes recognized thus far are small organisms (circa $450 \mathrm{~nm}$ or less) which form small colonies on solid media and have extensive nutritional requirements that make them very difficult to grow. Taxonomic distinctions among these organisms have proceeded slowly; initially the organisms were called the pleuropneumonia group, and in 1955 all such organisms were classified in one genus, Mycoplasma (family, Mycoplasmataceae; order, Mycoplasmatales) $(14,15)$. The family Acholeplasmataceae was formed in 1970 to include non-sterolrequiring species $(10,11)$, and in 1974 the family Mycoplasmataceae was subdivided into two genera, Mycoplasma and Ureaplasma (41) because of the unique ability of ureaplasmata to metabolize urea. Although the more than 52 species remaining in the genus Mycoplasma conform to the "minimal standards" for Mollicutes (i.e., they are smaller than $450 \mathrm{~nm}$, form typical small colonies, have no cell walls, and do not revert to bacteria [42]), these species have no other features in common except their dependence upon exogenous sterol for growth. The guanine-plus-cytosine $(\mathrm{G}+\mathrm{C})$ contents of their deoxyribonucleic acids vary; Mycoplasma pneumoniae has the highest $\mathrm{G}+\mathrm{C}$ content $(40$ mol\%), Mycoplasma gallisepticum has $34 \mathrm{~mol} \%$ $\mathrm{G}+\mathrm{C}$, and the $\mathrm{G}+\mathrm{C}$ contents of the remaining species range from approximately 23 to $30 \mathrm{~mol} \%$ (15). Bacteria which vary in $\mathrm{G}+\mathrm{C}$ content by more than $10 \mathrm{~mol} \%$ have little genetic relatedness (43), and the Mycoplasma species which have been tested differ from each other in $\mathrm{G}+\mathrm{C}$ content by more than $17 \mathrm{~mol} \%$ (37). Differences in metabolism include fermentation of glucose, or hydrolysis of arginine, or utilization of both substrates. An antigenic comparison of 23 species in which double immunodiffusion with a 
resolving power of 7 to 11 antigens was used showed that Mycoplasma species do not have any common antigen, as would be expected in a genus, and that there are distinct clusterings of species which correlate strongly with $\mathrm{G}+\mathrm{C}$ content, fermentation patterns, and nucleoside uptake $(21,24)$. Thus, we still do not know the relationships among the species classified in the genus Mycoplasma and the order Mycoplasmatales.

In this study we focused on the following two objectives: (i) to determine whether common enzymes of the Mycoplasmatales and Acholeplasmataceae are antigens, and (ii) if so, to determine whether the antigenic specificities of the enzymes differ among species. In the Mycoplasma and Acholeplasma species which we tested, which are representative of the serological clusters, we found that reduced nicotinamide adenine dinucleotide (NADH) dehydrogenase (EC 1.6.99.3) and adenosine triphosphatase
(ATPase) (EC 3.6.3.1) are antigens that are usually precipitated by homologous antisera. Cross-reactivity was demonstrated only within serologically related clusters of species, not between clusters.

\section{MATERIALS AND METHODS}

Organisms. A total of 14 strains representing seven serogroups of species as defined by Kenny $(23,24)$ were used in this study (Table 1). HeLa M cells (12) known to be mycoplasma-free were used in a control experiment.

Preparation of antigens. Strains were grown to densities of approximately $10^{8}$ cells per $\mathrm{ml}$ in a soy peptone-fresh yeast dialysate medium (20) containing $100 \mathrm{U}$ of penicillin per $\mathrm{ml}$ and supplemented as follows: Mycoplasma species, $10 \%$ agamma horse serum and $20 \mathrm{mM} N$-tris(hydroxymethyl)methyl-2-aminoethanesulfonic acid (TES) buffer at pH 7.3; Acholeplasma species, 2\% agamma horse serum, $10 \mathrm{mM}$ TES buffer (pH 7.3), and $5 \mathrm{mM}$ glucose; and Ureaplasma, 3\% agamma horse serum, $100 \mathrm{mM}$ 2-(N-morpholino)eth-

TABLE 1. Sources, identities, and characteristics of Mycoplasma, Acholeplasma, and Ureaplasma species

\begin{tabular}{|c|c|c|c|c|c|c|c|}
\hline Group $^{a}$ & Organism & $\begin{array}{l}\mathrm{G}+\mathrm{C} \text { content of } \\
\text { deoxyribonucleic } \\
\text { acid }(\mathrm{mol} \%)^{b}\end{array}$ & Glycolytic $^{b}$ & $\begin{array}{c}\text { Utilizes } \\
\text { arginine }^{b}\end{array}$ & $\begin{array}{c}\text { Uptake of } \\
\text { nucleosides }^{c}\end{array}$ & Source $^{d}$ & Reference \\
\hline 1 & $\begin{array}{l}\text { M. putrefaciens } \\
15718\end{array}$ & 28 & $t^{e}$ & - & + & ATCC & 46 \\
\hline 1 & $\begin{array}{l}M . \text { capricolum } \\
\text { type kid }\end{array}$ & 26 & + & $\mathbf{v}$ & NK & J. Tully & 46 \\
\hline 1 & $\begin{array}{l}\text { Mycoplasma } \\
\text { species bovine } \\
\text { group VII } \\
\text { strain N29B }\end{array}$ & NK & + & - & + & J. Tully & 7 \\
\hline 2 & $\begin{array}{l}\text { A. laidlawii } \\
14192\end{array}$ & 34 & + & - & + & ATCC & 28 \\
\hline 2 & $\begin{array}{l}\text { A. equifetale } \\
29724\end{array}$ & NK & + & - & NK & ATCC & 27 \\
\hline 4 & $\begin{array}{l}\text { M. gallisepticum } \\
15302\end{array}$ & 34 & + & - & + & ATCC & 1 \\
\hline 5 & $\begin{array}{l}\text { M. pneumoniae } \\
\text { AP164 }\end{array}$ & 40 & + & - & + & UW & 26 \\
\hline 5 & $\begin{array}{l}\text { M. pneumoniae } \\
\text { PN3546 }\end{array}$ & 40 & + & - & + & UW & \\
\hline 6 & M. felis $\mathrm{CO}$ & 25 & + & - & NK & B. Cole & 6 \\
\hline 7 & $\begin{array}{l}M . \text { arginini } \mathrm{G}- \\
230\end{array}$ & 28 & - & + & - & M. Barile & 47 \\
\hline 7 & $\begin{array}{l}\text { M. hominis } \\
14027\end{array}$ & 28 & - & + & - & ATCC & 50 \\
\hline 7 & $\begin{array}{l}\text { M. gallinarum } \\
15319\end{array}$ & 27 & - & + & NK & ATCC & 9 \\
\hline 7 & $\begin{array}{l}\text { M. gallinarum } \\
19708\end{array}$ & 27 & - & + & NK & ATCC & 9 \\
\hline $\mathrm{Un}^{f}$ & $\begin{array}{l}U . \text { urealyticum } \\
\text { serotype } 8, \\
\text { strain } 960\end{array}$ & 28 & - & - & NK & M. Shepard & 41 \\
\hline
\end{tabular}

a Serogroups proposed by Kenny $(23,24)$.

bee reference 15 .

c See reference 36.

d ATCC, American Type Culture Collection; UW, University of Washington.

- + , Positive; -, negative; v, variable (46); NK, not known.

$f$ Un, Ungrouped. This organism was not compared serologically with the other strains. 


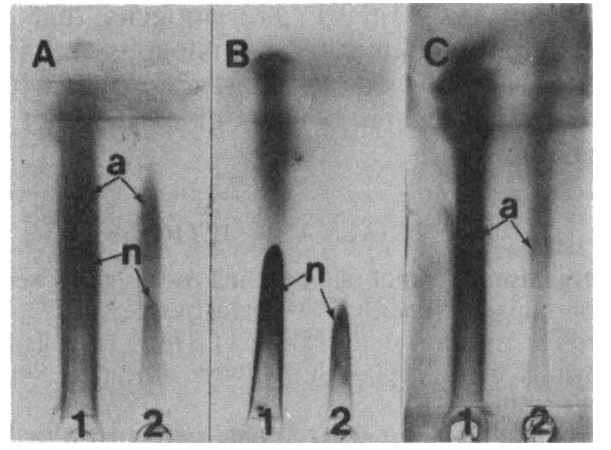

FIG. 1. Serological cross-reactivities of ATPase and NADH dehydrogenase in Acholeplasma (group 2). A. laidlawii antiserum was used. Lanes $1, A$. laidlawii antigen; lanes $2, A$. equifetale antigen. (A) Protein stain. (B) NADH dehydrogenase stain. (C) ATPase stain. The arrows indicate the positions of peaks for ATPase (a) and NADH dehydrogenase (n).

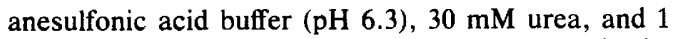
$\mathrm{mM} \mathrm{Na} \mathrm{SO}_{3}$ (25). When they were harvested, the organisms were centrifuged, washed twice in TESsaline (10 mM TES, $150 \mathrm{mM} \mathrm{NaCl}, \mathrm{pH} \mathrm{7.3),} \mathrm{suspended}$ in a small amount of distilled water, diluted to a density of approximately $4 \mathrm{mg}$ of protein per $\mathrm{ml}$, solubilized in $0.5 \%$ Triton $\mathrm{X}-100$ (a nonionic detergent), and disrupted by sonication for $60 \mathrm{~s}$. An anionic detergent, sodium deoxycholate $(0.1 \%)$, also was included in some preparations (see below). HeLa cells were grown to confluence in Eagle minimal essential medium (8) supplemented with $10 \%$ fetal calf serum. The cells were scraped off with a rubber policeman and suspended in TES-saline to a concentration of 4 $\mathrm{mg}$ of protein per $\mathrm{ml}$.

Preparation of antisera. Both the cultivation of immunogens and the immunization procedure for preparing antisera have been described previously $(22,25)$. To avoid raising antibodies to serum components, the species for immunization were grown in dialysate medium supplemented with agamma rabbit serum.

Immunoelectrophoresis. The procedure used for im- munoelectrophoresis was the technique described by Laurell (31), as modified by Thirkill and Kenny (45). Rocket immunoelectrophoresis was carried out on glass slides that were 2.5 by 7.5 or 5 by $7.5 \mathrm{~cm}$, and 4 by-4-cm glass slides were used for two-dimensional (crossed) immunoelectrophoresis. Slides were precoated with $0.5 \%$ agarose in water, dried, and then layered to a depth of $2 \mathrm{~mm}$ with an agarose support (a $0.5 \%$ solution of agarose in barbital buffer [ $\mathrm{pH} 8.6$; ionic strength, 0.05] and any detergent that had been used to solubilize the antigen). For rocket electrophoresis, the middle portion of the gel (approximately onehalf of the total volume) was excised and replaced with an equivalent amount of $0.5 \%$ agarose support to which 8 to $15 \%$ antiserum and $0.5 \%$ Triton X-100 had been added $(0.1 \%$ sodium deoxycholate was also included in runs with $U$. urealyticum). Holes $3 \mathrm{~mm}$ in diameter were cut at the cathodic end of the slide just below the antibody bed, antigen $(10 \mu \mathrm{l})$ was added to each well, and the slide was subjected to electrophoresis for 2 to $3 \mathrm{~h}$ at $3 \mathrm{~V} / \mathrm{cm}$. For two-dimensional immunoelectrophoresis, a $3-\mathrm{mm}$ well was cut $5 \mathrm{~mm}$ from the lower right corner, antigen $(10$ to $20 \mu \mathrm{l})$ was added, and electrophoresis was carried out for $1 \mathrm{~h}$ at 6 $\mathrm{V} / \mathrm{cm}$ with the anode to the left. The slide was turned $90^{\circ}$, all but a $1-\mathrm{cm}$ strip of agarose (which contained the separated antigens) was removed, and the agarose was replaced with an antibody bed. Electrophoresis of the second phase was carried out at $4 \mathrm{~V} / \mathrm{cm}$ for $6 \mathrm{~h}$ with the anode at the top. The electroendosmosis value $\left(-m_{r}\right)$ of the agarose support was 0.16 (measured by comparing the cathodic migration of dextran with the anodic migration of bovine albumin during electrophoresis) (49).

Enzyme stains. The procedures used for ATPase and NADH dehydrogenase zymograms were modifications of the procedures of Owen and Salton (39). After immunoelectrophoresis, gels were washed for 6 to $12 \mathrm{~h}$ in TES-saline to remove unreacted antigen and antibodies. The gels to be stained for ATPase were incubated unpressed at $37^{\circ} \mathrm{C}$ for 4 to $8 \mathrm{~h}$ (after which background staining became excessive) in a solution containing $10 \mathrm{mM}$ ATP Sigma Chemical Co., $10 \mathrm{mM}$ $\mathrm{MgSO}_{4}$, and $10 \mathrm{mM} \mathrm{Pb}\left(\mathrm{NO}_{3}\right)_{2}$ in $0.2 \mathrm{M}$ tris(hydroxymethyl)aminomethane hydrochloride (pH 7.5). Gels were pressed (48) with Whatman no. 1 filter paper for

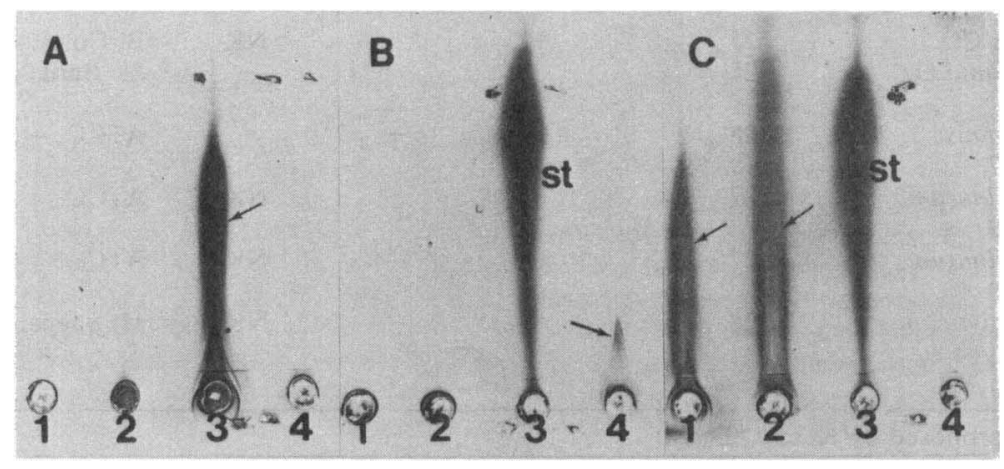

FIG. 2. Serological specificity of ATPases. Lanes 1, Mycoplasma species bovine group VII (group 1) antigen; lanes 2, M. putrefaciens (group 1) antigen; lanes 3, U. urealyticum antigen; lanes $4, M$. gallinarum (group 7) antigen. (A) $U$. urealyticum antiserum. (B) $M$. gallinarum antiserum. (C) $M$. capricolum antiserum. The arrows indicate the peaks formed by positive serological reactions. st, Streaking (nonspecific entrapment). 
$20 \mathrm{~min}$, washed in TES-saline, pressed two more times, and finally developed in a $0.1 \% \mathrm{Na}_{2} \mathrm{~S}$ solution. The final wash was distilled water to remove salt before the gels were dried. To stain for NADH dehydrogenase, after prewashing the gels were incubated at room temperature for up to $24 \mathrm{~h}$ in a solution containing $10 \mathrm{mg}$ of NADH (P-L Biochemicals or United States Biochemicals) and $5 \mathrm{mg}$ of tetranitroblue tetrazolium (Sigma Chemical Co.) per $20 \mathrm{ml}$ of $0.10 \mathrm{M}$ tris(hydroxymethyl)aminomethane hydrochloride $(\mathrm{pH}$ 6.8). The gels were then washed in distilled water and dried.

Protein assays. The protein contents of antigen samples were determined by the method of Lowry et al. (34), using bovine albumin as the standard. The gels to be stained for protein were washed for $24 \mathrm{~h}$ in TESsaline and for $6 \mathrm{~h}$ in distilled water, dried, and stained with Coomassie blue (5).

\section{RESULTS}

ATPase. ATPase was precipitated by homologous antisera in all species tested, as judged by zymograms of gels after rocket immunoelectrophoresis. When the enzyme was precipitated by antibody, a typical rocket-shaped peak was observed on the zymogram; this peak corresponded to a specific peak in a gel run simultaneously and stained for protein (Fig. 1). ATPase activity was also observed when the enzyme was trapped in the gel by nonspecific interaction. This streaking occurred when an enzyme that was apparently membrane associated (e.g., the ATPase of Ureaplasma urealyticum) was run through the agarose support gel alone (no antiserum), with serum from unsensitized rabbits (data not shown), or with heterologous antisera (Fig. 2). However, no precipitin lines were observed with Coomassie blue staining when entrapment was nonspecific, and the zymogram did not show a characteristic precipitin peak. If the enzyme was not recognized by the antiserum and was not entrapped, then the enzyme migrated completely off the slide if electrophoresis was continued long enough (Fig. 2). Increased electrophoresis time did not affect the peak heights of the enzymes precipitated by

TABLE 2. Serological specificities of ATPases and NADH dehydrogenases

\begin{tabular}{|c|c|c|c|c|c|c|c|c|c|c|c|c|c|}
\hline \multirow[b]{2}{*}{ Organism } & \multirow[b]{2}{*}{$\begin{array}{c}\text { Serolog- } \\
\text { ical } \\
\text { group }\end{array}$} & \multicolumn{12}{|c|}{ Antisera } \\
\hline & & $\begin{array}{c}\text { M. } \\
\text { putre- } \\
\text { faciens }\end{array}$ & $\begin{array}{c}\text { M. } \\
\text { capri- } \\
\text { colum }\end{array}$ & $\begin{array}{l}\text { Mycoplasma } \\
\text { sp. bovine } \\
\text { group VII }\end{array}$ & $\begin{array}{c}\text { A. } \\
\text { laid- } \\
\text { lawii }\end{array}$ & $\begin{array}{c}A \\
\text { equi- } \\
\text { fetale }\end{array}$ & $\begin{array}{l}M . \text { galli- } \\
\text { septicum }\end{array}$ & $\begin{array}{c}M . \\
\text { pneu- } \\
\text { moniae } \\
\text { AP164 }\end{array}$ & $\begin{array}{c}\text { M. } \\
\text { felis }\end{array}$ & $\begin{array}{c}\text { M. } \\
\text { homi- } \\
\text { nis }\end{array}$ & $\begin{array}{c}M . \\
\text { argin- } \\
\text { ini }\end{array}$ & $\begin{array}{c}M . \\
\text { galli- } \\
\text { nar- } \\
\text { um } \\
15319\end{array}$ & $\begin{array}{c}U . \\
\text { urealy- } \\
\text { ticum }\end{array}$ \\
\hline $\begin{array}{l}\text { M. putrefa- } \\
\text { ciens }\end{array}$ & 1 & $+^{a}$ & + & + & - & - & - & - & - & - & - & - & - \\
\hline $\begin{array}{l}\text { lum } \\
\text { luprico- }\end{array}$ & 1 & + & + & + & - & - & - & - & - & - & - & - & - \\
\hline $\begin{array}{c}\text { Mycoplasma } \\
\text { sp. bovine } \\
\text { group VII }\end{array}$ & 1 & + & + & + & - & - & - & - & - & - & - & - & - \\
\hline A. laidlawii & 2 & - & - & - & + & + & - & - & - & - & - & - & - \\
\hline A. equifetale & 2 & - & - & - & + & + & - & - & - & - & - & - & - \\
\hline $\begin{array}{l}\text { M. gallisepti- } \\
\text { cum }\end{array}$ & 4 & - & - & - & - & - & + & - & - & - & - & - & - \\
\hline $\begin{array}{l}\text { M. pneumo- } \\
\quad \text { niae } \\
\text { AP164 }\end{array}$ & 5 & - & - & - & - & - & - & + & - & - & - & - & - \\
\hline $\begin{array}{l}\text { M. pneumo- } \\
\quad \text { niae } \\
\text { PN3546 }\end{array}$ & 5 & - & - & - & - & - & - & + & - & - & - & - & - \\
\hline M. felis & 6 & - & - & - & - & - & - & - & $\mathbf{A}$ & - & - & - & - \\
\hline M. hominis & 7 & - & - & - & - & - & - & - & - & $\mathbf{A}$ & $\mathbf{A}$ & - & - \\
\hline $\begin{array}{l}\text { M. arginini } \\
\text { M. gallin- }\end{array}$ & 7 & - & - & - & - & - & - & - & - & $\mathbf{A}$ & $\mathbf{A}$ & - & - \\
\hline $\begin{array}{l}\text { arum } \\
15319\end{array}$ & 7 & - & - & - & - & - & - & - & - & - & - & + & - \\
\hline $\begin{array}{l}\text { M. gallin- } \\
\text { arum } \\
19708\end{array}$ & 7 & - & - & - & - & - & - & - & - & - & - & + & - \\
\hline $\begin{array}{l}U . \text { urealyti- } \\
\text { cum }\end{array}$ & $\mathrm{Un}^{b}$ & - & - & - & - & - & - & - & - & - & - & - & $t^{c}$ \\
\hline
\end{tabular}

${ }^{a}+$, Positive for both ATPase and NADH dehydrogenase antibodies; A, positive for ATPase antibody only; -, enzymes not reactive with antibody.

${ }^{b}$ Un, Ungrouped. This organism was not compared serologically with the other organisms.

c NADH dehydrogenase was not detected in this organism. 


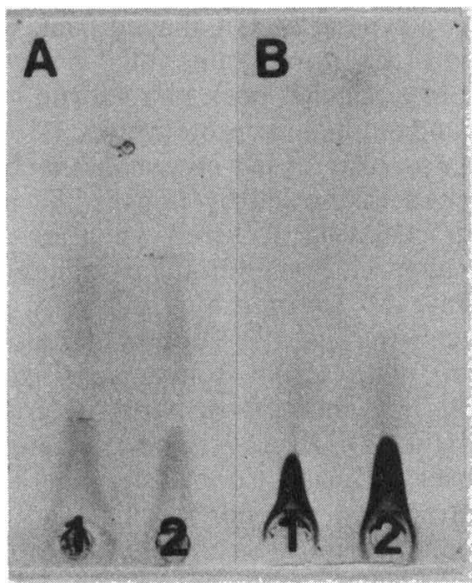

FIG. 3. Cross-reactivity of enzymes from two strains of $M$. pneumoniae (group 5). Lanes $1, M$. pneumoniae AP164; lanes 2, $M$. pneumoniae PN3546. $M$. pneumoniae PN3546 antiserum was used. (A) ATPase stain. (B) NADH dehydrogenase stain.

specific antibody. Serological relatedness among the species was reflected in the serological specificities of their ATPases. Antiserum to one member of a species group usually precipitated the ATPases of other species belonging to the same group, but never precipitated ATPases from members of other groups (Table 2). When antigens from Mycoplasma putrefaciens and bovine group VII (group 1), Mycoplasma gallinarum (group 7), and $U$. urealyticum were tested against antisera to Mycoplasma capricolum, $M$. gallinarum, and $U$. urealyticum, only group 1

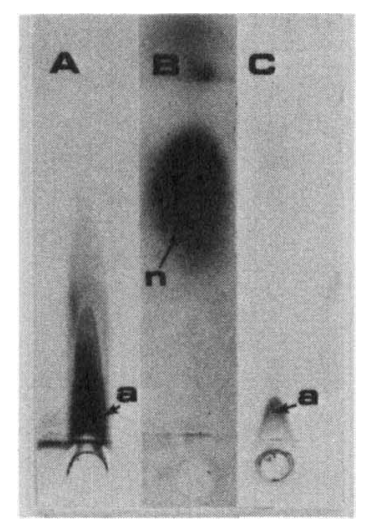

FIG. 4. Demonstration of a specific precipitin reaction for ATPase but not NADH dehydrogenase from $M$. felis (group 6). M. felis antigen and homologous antibody were used. (A) Protein stain. (B) NADH dehydrogenase stain. (C) ATPase stain. The arrows indicate the positions of ATPase (a) and NADH dehydrogenase (n). The ATPase peak in the protein stain preparation is obscured by a larger peak.
ATPases were precipitated by group 1 antisera. Antibody to $M$. gallinarum precipitated only the $M$. gallinarum enzyme, and only $U$. urealyticum ATPase was precipitated by antiserum to that species (Fig. 2). Cross-reactions between Acholeplasma laidlawii and Acholeplasma equifetale were examined by using rocket electrophoresis and antibody to $A$. laidlawii. $A$. laidlawii ATPase was strongly precipitated by homologous antibody, whereas the $A$. equifetale enzyme had a weaker but positive reaction (Fig. 1). Antiserum to either $M$. pneumoniae strain (group 5) precipitated the ATPases of both strains equally (Fig. 3). The one strain of $M$. gallisepticum which represented group 4 had an antigenically distinct ATPase which did not react with any other group (data not shown). The enzyme of Mycoplasma felis (Fig. 4) did not cross-react outside group 6 . The fact that a particular antigen (ATPase) was identified was important in determining relationships among group 7 species. Although the group 7 species chosen for this study have been shown to crossreact by gel diffusion and crossed immunoelectrophoresis $(23,24)$, the serological specificities of the group 7 ATPases differed. Two group 7 species, Mycoplasma arginini and Mycoplasma hominis, had enzymes that were precipitated by antibody to $M$. arginini (data not shown) but not by antibody to $M$. gallinarum, which reacted only with $M$. gallinarum enzyme (Fig. 5).

NADH dehydrogenase. NADH dehydrogenase activity was observed by zymogram in each of the species studied except $U$. urealyticum, in which this enzyme was not demonstrated. The enzyme was serologically reactive (i.e., it was precipitated by homologous antisera) in groups $1,2,4$, and 5 . The $M$. felis enzyme (group 6) migrated through the antibody bed without being precipitated (Fig. 4), but could be demonstrated

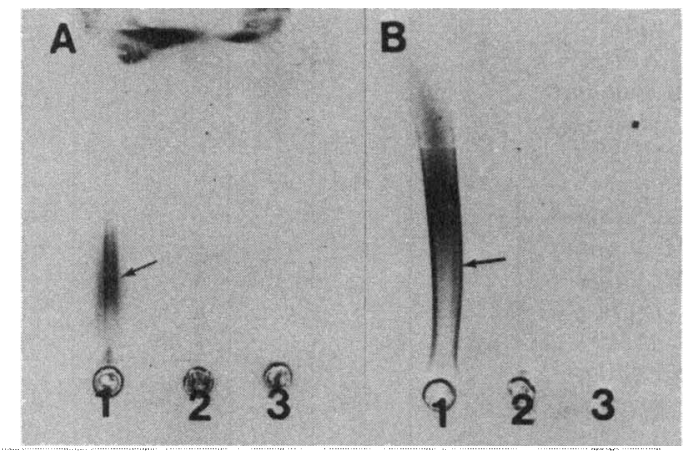

FIG. 5. Serological heterogeneity of enzymes from group 7. Lanes $1, M$. gallinarum antigen; lanes $2, M$. hominis antigen; lanes $3, M$. arginini antigen. $M$. gallinarum antiserum was used. (A) ATPase stain. (B) NADH dehydrogenase stain. The arrows indicate positive serological reactions. 


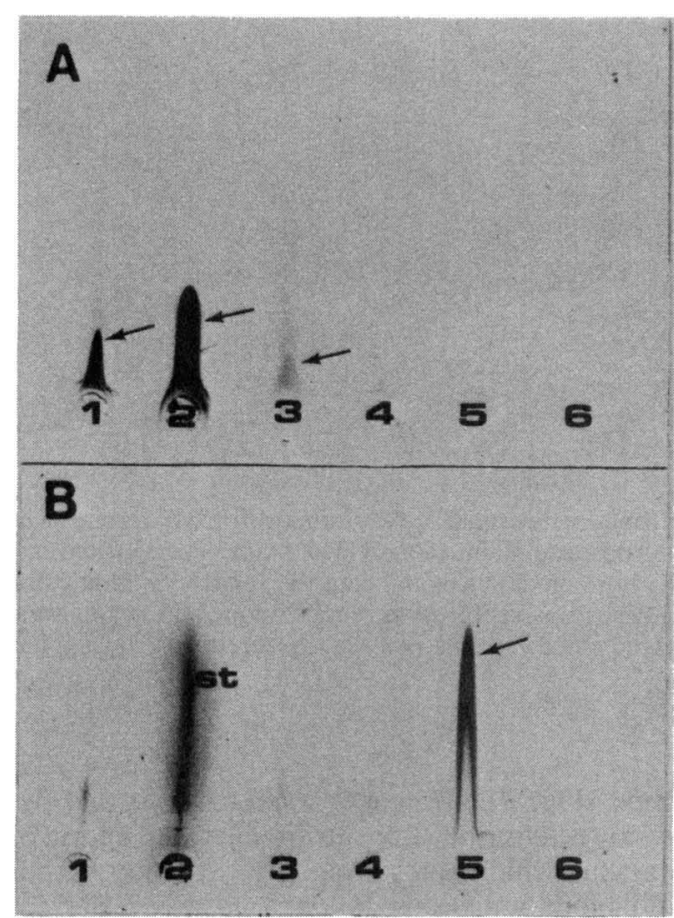

FIG. 6. Serological specificities of NADH dehydrogenase. Lanes $1, M$. capricolum (group 1) antigen; lanes 2, $M$. putrefaciens (group 1) antigen; lanes 3, Mycoplasma species bovine group VII (group 1) antigen; lanes 4, M. gallisepticum (group 4) antigen; lanes 5, M. gallinarum (group 7) antigen; lanes 6, mammalian NADH dehydrogenase antigen. (A) $M$. putrefaciens antiserum. (B) $M$. gallinarum antiserum. The arrows indicate positive serological reactions.

by halting the electrophoresis before the enzyme migrated off the slide and staining the gel by zymogram. Antiserum to $M$. felis detected other antigens (which could be revealed by protein staining), but failed to react with any NADH dehydrogenase. In addition, antisera to species in other groups did not react serologically with the $M$. felis enzyme. Among the group 7 species, $M$. gallinarum contained a serologically reactive enzyme, whereas neither $M$. hominis nor $M$. arginini was serologically reactive; the enzymes of these species were not precipitated by homologous antisera, by antiserum to $M$. gallinarum (which reacted with its own group 7 enzyme), or by antiserum to any other species (Fig. 5). Reactions of enzymes from one group with antisera to species belonging to other groups demonstrated that cross-reactions occurred within groups but not between groups (Table 2). It is noteworthy that in species having serologically reactive NADH dehydrogenases, the specificities of this enzyme exactly paralleled those of ATPase. Group 1 NADH dehydrogenases reacted with antiserum to $M$. putrefaciens (a group 1 organism), showing that the enzymes of all three species cross-reacted, whereas antibody to $M$. gallinarum (group 7) did not precipitate group 1 enzymes (Fig. 6). Antiserum to $A$. laidlawii (group 2) precipitated enzymes of both $A$. laidlawii and $A$. equifetale (Fig. 1). The two M. pneumoniae strains (group 5) cross-reacted (Fig. 3). Neither $M$. gallisepticum NADH dehydrogenase (group 4) nor a standard mammalian NADH dehydrogenase from pig heart (Sigma) used at an identical protein concentration reacted with antisera to group 1 or group 7 organisms (Fig. 6).

Electrophoretic mobility. The enzyme peaks were identified by zymogram in two-dimensional immunoelectrophoresis gels, and these peaks were compared with the peaks on an identical slide stained for protein. When a protein-stained profile was compared with the zymograms for ATPase and NADH dehydrogen-
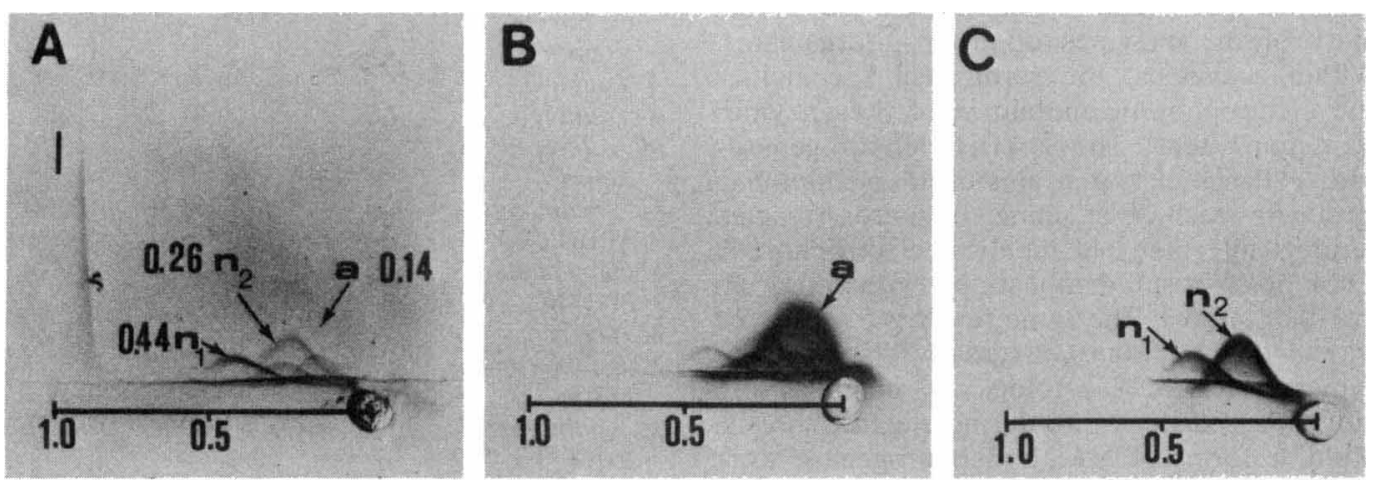

FIG. 7. Identification of enzymes in a crossed immunoelectrophoresis profile of $M$. pneumoniae AP164 (group 5) in homologous antiserum. (A) Protein stain. (B) ATPase stain. (C) NADH dehydrogenase stain. The arrows indicate the locations of ATPase (a) and two electrophoretic forms of NADH dehydrogenase $\left(n_{1}\right.$ and $\left.n_{2}\right)$. ATPase is not revealed by protein staining. The vertical bar indicates the center of the bovine albumin marker. The horizontal scales indicate the relative mobilities of antigens. 


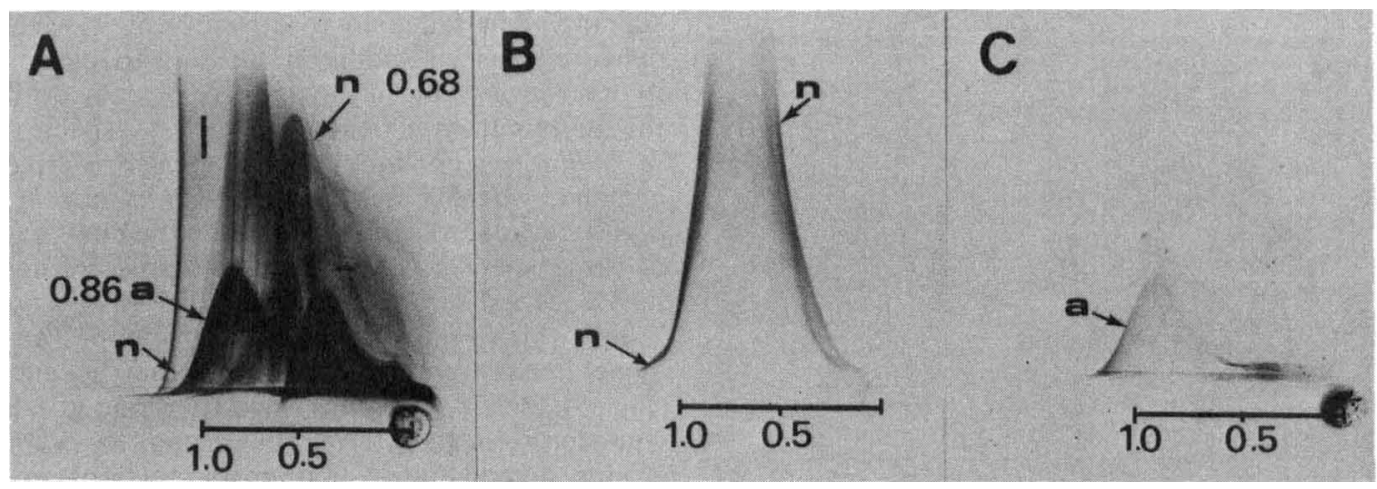

FIG. 8. Locations of enzymes in a crossed immunoelectrophoresis profile of $M$. gallinarum 15319 (group 7) in homologous antibody. (A) Protein stain. (B) NADH dehydrogenase stain. (C) ATPase stain. The vertical bar indicates the center of the bovine albumin marker, and the horizontal scales indicate the relative mobilities of antigens. The arrows indicate the locations of enzymes. ATPase (a) is visible by protein staining and zymogram. The two sides of the NADH dehydrogenase (n) peak are indicated, as this peak is obscured by overlapping antigens.

ase, we found that both enzymes were precipitated by homologous antiserum in most species tested. The relative electrophoretic mobilities were then determined by comparison with the bovine albumin standard (Fig. 7 and 8). The electrophoretic mobilities of enzymes in agarose did not distinguish between serologically unrelated enzymes, nor were the mobilities consistent among enzymes which had been shown to be related serologically (Table 3 ). The same mobility was observed for the NADH dehydrogenases of bovine group VII (group 1) and the Acholeplasma species (group 2), although the enzymes from groups 1 and 2 did not cross-react. Similarly, the unrelated ATPases of $M$. gallisepticum and $M$. felis moved at the same relative rate in agarose. Both enzymes of $M$. putrefaciens showed different mobilities than the enzymes of other members of group 1, despite the demonstrated serological cross-reactivity of the enzymes of group 1 organisms. Within a species, the serological specificities and electrophoretic mobilities of the enzymes were consistent. The NADH dehydrogenases and ATPases of two strains of $M$. pneumoniae (group 5) which we examined both cross-reacted serologically and had identical electrophoretic mobilities (a result demonstrable with antiserum to either strain). The same result was observed with two $M$. gallinarum (group 7) strains; enzymes which were serologically identical also moved at the same rate during electrophoresis. Multiple forms of NADH dehydrogenase were found in several species. Antiserum to either strain of $M$. pneumoniae precipitated two electrophoretically distinct forms of the enzyme; these forms were also detected by protein staining and may constitute major cytoplasmic anti- gens (Fig. 7). $M$. gallinarum (Fig. 8) and $M$. putrefaciens (data not shown) each had a form of enzyme which was precipitated strongly by homologous antiserum, as well as other electrophoretic forms which were precipitated poorly and were not always observed. The electrophoretic mobility of the ATPase of $U$. urealyticum could not be determined by two-dimensional

TABLE 3. Electrophoretic mobilities of enzymes relative to bovine serum albumin

\begin{tabular}{|c|c|c|c|}
\hline \multirow[b]{2}{*}{ Organism } & \multirow{2}{*}{$\begin{array}{c}\text { Serolog } \\
\text { ical } \\
\text { group }\end{array}$} & \multicolumn{2}{|c|}{$\begin{array}{l}\text { Electrophoretic } \\
\text { mobility }^{a}\end{array}$} \\
\hline & & $\begin{array}{c}\text { NADH } \\
\text { dehydro- } \\
\text { genase }\end{array}$ & ATPase \\
\hline M. putrefaciens & 1 & $0.40,0.25$ & 0.60 \\
\hline M. capricolum & 1 & 0.50 & 0.80 \\
\hline $\begin{array}{c}\text { Mycoplasma } \\
\text { sp. bovine } \\
\text { group VII }\end{array}$ & 1 & 0.55 & $\mathbf{N S}^{b}$ \\
\hline A. laidlawii & 2 & 0.55 & NS \\
\hline A. equifetale & 2 & 0.55 & NS \\
\hline $\begin{array}{l}\text { M. gallisepti- } \\
\text { cum }\end{array}$ & 4 & 0.32 & 0.55 \\
\hline $\begin{array}{l}\text { M. pneumoniae } \\
\text { AP164 }\end{array}$ & 5 & $0.44,0.26$ & 0.14 \\
\hline $\begin{array}{l}\text { M. pneumoniae } \\
\text { PN3546 }\end{array}$ & 5 & $0.44,0.26$ & 0.14 \\
\hline M. felis & 6 & $\mathrm{NS}^{c}$ & 0.55 \\
\hline $\begin{array}{l}\text { M. gallinarum } \\
15319\end{array}$ & 7 & $1.1,0.68$ & 0.83 \\
\hline $\begin{array}{l}\text { M. gallinarum } \\
19708\end{array}$ & 7 & $1.1,0.68$ & 0.86 \\
\hline
\end{tabular}

${ }^{a}$ Electrophoretic mobility relative to bovine albumin in two-dimensional immunoelectrophoresis.

${ }^{b}$ NS, Not seen (peak too weak to see on a twodimensional zymogram).

${ }^{c}$ No precipitin reaction. 
immunoelectrophoresis because enzyme activity was restricted to a streak at the base of the slide. Streaking was reduced but not eliminated by including a negatively charged detergent ( $0.1 \%$ sodium deoxycholate), which moves amphiphilic proteins more rapidly toward the anode $(2,18)$. In the Acholeplasma species, M. hominis, and $M$. arginini, ATPase activity was too weak compared with the background stain in the two-dimensional zymograms to discern the position of the peak. NADH dehydrogenase was not precipitated by antisera in $M$. felis, $M$. arginini, and $M$. hominis.

Sensitivity. Zymograms were often more sensitive than protein staining for locating an enzyme peak. Although the NADH dehydrogenase of $M$. pneumoniae was clearly shown by protein staining, ATPase was detected only by enzyme staining (Fig. 7). The ATPase in the $M$. gallinarum profile was discernible by protein staining; the NADH dehydrogenase showed strong enzymatic activity, whereas the companion protein stain was very faint (Fig. 8). U. urealyticum ATPase was detected only in rocket electrophoresis by zymogram; slides stained for proteins showed no peak comparable to the ATPase peak (Fig. 9). In $M$. felis the ATPase peak was obscured by a strongly stained protein peak and was visible only by zymogram (Fig. 4). The intensified ATPase stain gave a degree of nonspecific staining (or illumination) of peaks visible by protein staining (Fig. 7B), but the specific stain of the enzyme was far more intense than the nonspecific illumination of other antigen peaks.

Controls. Rabbit antisera to mycoplasmic immunogens did not detect horse serum enzymes in mycoplasmic antigen preparations. HeLa cell antigens showed ATPase and NADH dehydrogenase which reacted with homologous antiserum but not with antisera to Mycoplasma species. It has been shown that Triton X-100 has strongly oxidizing impurities present in some preparations, and these impurities have been suspected of interference in enzyme assays (4) where a reduced product is the indicator. To test for possible interference in our assay for NADH dehydrogenase, which involved the reduction of a tetrazolium salt, assays were done on antigens run without Triton $X-100$. The same number of enzyme peaks and the same apparent enzyme activity were observed. An additional source of potential interference in enzyme assays for which we tested was the substrate for NADH dehydrogenase. Contaminants in commercial preparations of NADH are known to inhibit certain dehydrogenases $(19,29)$. Although NADH dehydrogenase has not been implicated, in order to avoid this problem solutions were made fresh from NADH that had been kept

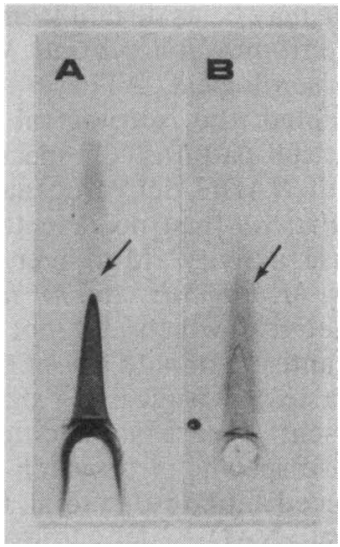

FIG. 9. Comparison of protein staining (A) and an ATPase zymogram (B) in a rocket immunoelectrophoresis profile of $U$. urealyticum in homologous antiserum. The arrows indicate the position of the ATPase peak, which is not revealed by protein staining.

scrupulously dehydrated (35). In addition, antigens were tested with a chromatographically purified preparation of NADH. When substrate was omitted, no staining occurred with either enzyme stain.

\section{DISCUSSION}

The concept that all sterol-requiring, nonhelical, urease-negative, membrane-bound procaryotes can be classified into a single genus ( $\mathrm{Myco}$ plasma) or, indeed, that all wall-less procaryotes can be classified into one order (Mycoplasmatales) has been seriously questioned by the results of recent studies $(13,51)$. A comparison of $16 \mathrm{~S}$ ribosomal ribonucleic acid oligonucleotides suggested that there has been degenerative evolution of certain Mycoplasma species (evidently by diverse pathways) from the family Bacillaceae (51). By these criteria, $M$. capricolum (group 1) appears to be more closely related to Spiroplasma citri than to $M$. gallisepticum (group 4), and A. laidlawii (group 2) is more closely related to Clostridia innocuum than to $M$. capricolum. Previous antigenic analyses of the Mycoplasmatales have revealed at least seven clusters of species $(21,24)$. One of these clusters, the family Acholeplasmataceae, has at least one cytoplasmic antigen which is common to all Acholeplasma species (32) but which is not shared with the family Mycoplasmataceae. Since present data show no evidence of common antigens in the various species of the genus Mycoplasma, we studied the serological specificities of ATPase and NADH dehydrogenase, which are present in all Mycoplasma and Acholeplasma species. Our results indicate that the remaining serological clusters in the $\mathrm{Myco}$ - 
plasmataceae may be as distant from one another as they are from Acholeplasma. We detected six distinct serological ATPase specificities, which paralleled the serological groupings. Nearly identical patterns of specificity were observed with NADH dehydrogenases, except that $U$. urealyticum had no detectable NADH dehydrogenase activity. Moreover, three species (M. felis, M. hominis, and $M$. arginini) had enzymatic activity which did not react with homologous antisera or with any of the heterologous antisera tested, suggesting that these enzymes represent at least one additional NADH dehydrogenase specificity to which none of the rabbits produced antibody. In total, five serologically distinct NADH dehydrogenases were found in the 10 species which had serologically detectable NADH dehydrogenase activity.

The antigenic distinctiveness of ATPase and NADH dehydrogenase, as well as the ability of these enzymes to cluster apparently related organisms, has considerable taxonomic importance. We are now able to assign specific functions to common and unique antigens. This answers the following problem, which was posed by Lemcke (33): "Until . . . the serological determinants of the mycoplasmas can be interpreted in terms of chemically defined determinants, we are forced to make the most intelligent use we can of our serological comparisons." First, the antigenic specificities of ATPase and NADH dehydrogenase can be used as two positive criteria to bind group 1 species together. This is important because the prototypic species of the genus Mycoplasma ( $\mathrm{Myco}$ plasma mycoides var. mycoides, an organism which cannot be studied in the United States) is closely related to this group $(23,24)$. Since no cross-reactions for these two enzymes were observed with other groups of species, group 1 species could be separated from the rest of the organisms in the genus Mycoplasma. Second, intragroup specificities may be detected. $M$. gallinarum is an arginine utilizer which is antigenically related to other group 7 species, but this species shares the fewest antigens with that group (45). Both the ATPase and the NADH dehydrogenase of $M$. gallinarum showed distinct antigenic specificities. The arginine deiminase of this organism also has a different serological specificity than the arginine deiminases of $M$. arginini and $M$. hominis (16).

In contrast, a comparison of the electrophoretic mobilities of a given enzyme did not lead to any clustering of species compatible with enzyme antigenic specificity. Isoenzymes which represented different antigenic specificities frequently had similar mobilities, whereas antigenically related isoenzymes sometimes had different mobilities (Table 3). This conclusion is in accord with the results of previous studies. Sugino (44) found that the electrophoretic mobilities of thymidine kinases showed substantial differences both between and among Mycoplas$m a$ and Acholeplasma species. When O'Brien et al. (38) tested 22 Mycoplasma and Acholeplasma species for common enzymes (using procedures for staining human serum enzymes), they detected 12 different enzymes having varying mobilities. However, when the data of these authors (38), as well as the data of Sugino (44), were compared with serological clustering, no relationship between serological groups and electrophoretic mobilities could be detected.

The technology of staining immunoprecipitates for enzymes is relatively simple since there are a variety of histochemical stains which can be directly adapted to crossed immunoelectrophoresis $(17,39)$. Staining for enzyme activity has frequently but not always been more sensitive for detecting precipitin peaks than Coomassie blue staining. However, it is essential to remember that the fact that a given precipitin line is positive for a specific enzyme activity does not necessarily imply that the antibody is specific to that enzyme, since the antibody may only be specific to molecules associated with that enzyme. This problem is most likely to occur with membrane-associated enzymes; nevertheless, we were able to distinguish the antigenic activity of NADH dehydrogenase from the activity of ATPase in A. laidlawii, in which both enzymes are known to be membrane associated $(30,40)$. The presence of a great many detectable enzymes in mycoplasmata (38) indicates that additional surveys for antigenic activity will be useful. The ability to prepare monospecific antisera (3) to individual enzymes should increase the usage of serological specificities of enzymes for taxonomic purposes. Enzymes are protein products of the genetic machinery and thus may be sensitive indicators of evolutionary and phylogenetic relationships.

\section{ACKNOWLEDGMENT}

This research was supported in part by Public Health Service grant AI-06720 from the National Institute of Allergy and Infectious Diseases.

\section{LITERATURE CITED}

1. Adler, H. E., J. Fabricant, R. Yamomoto, and J. Berg. 1958. Symposium on chronic respiratory diseases of poultry. I. Isolation and identification of pleuropneumonia-like organisms of avian origin. Am. J. Vet. Res. 19:440-447.

2. Alexander, A. G., and G. E. Kenny. 1978. Application of charge shift electrophoresis to antigenic analysis of mycoplasmic membranes by two-dimensional (crossed) immunoelectrophoresis. Infect. Immun. 20:483-489.

3. Alexander, A. G., and G. E. Kenny. 1980. Characterization of the strain-specific and common surface antigens of Mycoplasma arginini. Infect. Immun. 29:442-451.

4. Ashani, Y., and G. N. Catravas. 1980 . Highly reactive 
impurities in Triton X-100 and Brij 35: partial characterization and removal. Anal. Biochem. 109:55-62.

5. Axelsen, N. H., and E. Bock. 1972. Identification and quantitation of antigens and antibodies by means of quantitative immunoelectrophoresis. A survey of methods. J. Immunol. Methods 1:109-121.

6. Cole, B. C., L. Golightly, and J. R. Ward. 1967. Characterization of mycoplasma strains from cats. J. Bacteriol. 94:1451-1458.

7. Cottew, G. S., and R. S. Leach. 1969. Mycoplasmas of cattle, sheep and goats, p. 527-570. In L. Hayflick (ed.), The Mycoplasmatales and the L-phase of bacteria. Appleton-Century-Crofts, New York.

8. Eagle, H. 1959. Amino acid metabolism in mammalian cell cultures. Science 130:432-437.

9. Edward, D. G. ff. 1954. The pleuropneumonia group of organisms: a review, together with some new observations. J. Gen. Microbiol. 10:27-64.

10. Edward, D. G. ff., and E. A. Freundt. 1969. Proposal for classifying organisms related to Mycoplasma laidlawii in a family Sapromycetaceae, genus Sapromyces, with the Mycoplasmatales. J. Gen. Microbiol. 57:391-395.

11. Edward, D. G. ff., and E. A. Freundt. 1970. Amended nomenclature for strains related to Mycoplasma laidlawii. J. Gen. Microbiol. 62:1-2.

12. Fiala, M., and G. E. Kenny. 1966. Enhancement of rhinovirus plaque formation in human heterophoid cell cultures by magnesium and calcium. J. Bacteriol. 92:1710-1715.

13. Fox, G. E., E. Stackebrandt, R. B. Hespell, J. Gibson, J. Maniloff, T. A. Dyer, R. S. Wolfe, W. E. Balch, R. S. Tanner, L. J. Magrum, L. B. Zablen, R. Blakemore, R. Gupta, L. Bonen, B. J. Lewis, D. A. Stahl, K. R. Luehrsen, K. N. Chen, and C. R. Woese. 1980 . The phylogeny of prokaryotes. Science 209:457-463.

14. Freundt, E. A. 1955. A suggested classification and nomenclature for organisms of the pleuropneumonia group. Int. Bull. Bacteriol. Nomencl. Taxon. 5:85-93.

15. Freundt, E. A., and D. G. It. Edward. 1979. Classification and taxonomy, p. 1-41. In M. F. Barile and S. Razin (ed.), The mycoplasmas, vol. 1. Academic Press, Inc., New York.

16. Hahn, R. G., and G. E. Kenny. 1974. Differences in arginine requirement for growth among arginine-utilizing Mycoplasma species. J. Bacteriol. 117:611-618.

17. Harris, H., and D. A. Hopkinson. 1976. Handbook of enzyme electrophoresis in human genetics. North-Holland Publishing Co., Amsterdam.

18. Helenius, A., and K. Simons. 1977. Charge shift electrophoresis: a simple method for distinguishing between amphiphilic and hydrophilic proteins in detergent solution. Proc. Natl. Acad. Sci. U.S.A. 74:529-532.

19. Kaplan, A. E., E. R. Weiss, S. T. Byrne, N. M. El-Torkey, and S. A. Margolis. 1981. Purified reduced nicotinamide adenine dinucleotide: responses to lactate dehydrogenase isozymes from three cell sources. Science 212:553-554.

20. Kenny, G. E. 1967. Heat stability and organic solvent solubility of mycoplasma antigens. Ann. N.Y. Acad. Sci. 143:676-681.

21. Kenny, G. E. 1969. Serological comparison of ten glycolytic Mycoplasma species. J. Bacteriol. 98:1044-1055.

22. Kenny, G. E. 1971. Immunogenicity of Mycoplasma pneumoniae. Infect. Immun. 3:510-515.

23. Kenny, G. E. 1977. Antigenic analysis of the Mycoplasmatales, p. 376-382. In H. Hobson and K. Holmes (ed.), Nongonococcal urethritis and related infections. American Society of Microbiology, Washington, D.C.

24. Kenny, G. E. 1979. Antigenic determinants, p. 351-384. In M. F. Barile and S. Razin (ed.), The mycoplasmas, vol. 1. Academic Press, Inc., New York.

25. Kenny, G. E., and F. D. Cartwright. 1977. Effect of urea concentration on growth of Ureaplasma urealyticum (T. strain mycoplasma). J. Bacteriol. 132:144-150.

26. Kenny, G. E., and J. T. Grayston. 1965. Eaton pleuro- pneumonia-like organism (Mycoplasma pneumonia) complement-fixing antigen: extraction with organic solvents. J. Immunol. 95:19-25.

27. Kirchhoff, H. 1978. Acholeplasma equifetale and Achole plasma hippikon, two new species from aborted horse fetuses. Int. J. Syst. Bacteriol. 28:76-81.

28. Klieneberger, E. 1940. The pleuropneumonia-like organisms. Further comparative studies and a descriptive account of recently discovered types. J. Hyg. 40:204-222.

29. Klotzsch, S. G., and H. R. Klotzsch. 1969. Inhibitor-contaminated NADH: its influence on dehydrogenases and dehydrogenase-coupled reactions. Clin. Chem. 15:10561061.

30. Larraga, V., and S. Razin. 1976. Reduced nicotinamide adenine dinucleotide oxidase activity in membranes and cytoplasm of Acholeplasma laidlawii and Mycoplasma mycoides subsp. capri. J. Bacteriol. 128:827-833.

31. Laurell, C. B. 1965. Antigen-antibody crossed electrophoresis. Anal. Biochem. 10:358-361.

32. Lee, G. Y., and G. E. Kenny. 1983. Common cytoplasmic antigen in five Acholeplasma species. Int. J. Syst. Bacteriol. 33:358-365.

33. Lemcke, R. M. 1973. Serological reactions of mycoplasmas. Ann. N.Y. Acad. Sci. 225:46-53.

34. Lowry, O. H., N. J. Rosebrough, A. L. Farr, and R. J. Randall. 1951. Protein measurement with the Folin reagent. J. Biol. Chem. 193:265-275.

35. Margolis, S. A., B. F. Howell, and R. Schaffer. 1976. Purification and analysis of the purity of NADH. Clin. Chem. 22:1322-1329.

36. McIvor, R. S., and G. E. Kenny. 1978. Differences in incorporation of nucleic acid bases and nucleosides by various Mycoplasma and Acholeplasma species. J. Bacteriol. 135:483-489.

37. Neimark, H. C. 1970. Division of mycoplasmas into subgroups. J. Gen. Microbiol. 63:249-263.

38. O'Brien, S. J., J. M. Simonson, M. W. Grabowski, and M. F. Barile. 1981. Analysis of multiple isoenzyme expression among twenty-two species of Mycoplasma and Acholeplasma. J. Bacteriol. 146:222-232.

39. Owen, P., and M. R. J. Salton. 1975. Antigenic and enzymatic architecture of Micrococcus lysodeikticus membranes established by crossed immunoelectrophoresis. Proc. Natl. Acad. Sci. U.S.A. 72:3711-3715.

40. Pollack, J. D., S. Razin, and R. C. Cleverdon. 1965. Localization of enzymes in Mycoplasma. J. Bacteriol. 90:617-622.

41. Shepard, M. C., C. D. Lunsford, D. K. Ford, R. H. Purcell, D. Taylor-Robinson, S. Razin, and F. T. Black. 1974. Ureaplasma urealyticum gen. nov., sp. nov.: proposed nomenclature for the human $\mathrm{T}$ (T-strain) mycoplasmas. Int. J. Syst. Bacteriol. 24:160-171.

42. Subcommittee on the Taxonomy of Mollicutes. 1979. Proposal of minimal standards for descriptions of new species of the class Mollicutes. Int. J. Syst. Bacteriol. 29:172-180.

43. Sueoka, N. 1961. Variation and heterogeneity of base composition of deoxyribonucleic acids: a compilation of old and new data. J. Mol. Biol. 3:31-40.

44. Sugino, W. M. 1980 . Heterogeneity of thymidine kinase among species of Mycoplasma and Acholeplasma. Int. J. Syst. Bacteriol. 30:103-105.

45. Thirkill, C. E., and G. Kenny. 1974. Serological comparison of five arginine-utilizing Mycoplasma species by twodimensional immunoelectrophoresis. Infect. Immun. 10:624-632.

46. Tully, J. G., M. F. Barile, D. G.r. Edward, T. S. Theodore, and H. Erno. 1974. Characterization of some caprine mycoplasmas, with proposals for new species, $M$. capricolum and $M$. putrefaciens. J. Gen. Microbiol. $\bullet: 102-$ 120.

47. Tully, J. G., R. A. Del Giudice, and M. F. Barile. 1972. Synonomy of Mycoplasma arginini and Mycoplasma leonis. Int. J. Syst. Bacteriol. 22:47-55.

48. Weeke, B. 1973. Equipment, reagents, procedures, p. 37 
46. In H. Axelsen, J. Kroll, and B. Weeke (ed.), A manual of quantitative immunoelectrophoresis: methods and applications. Universitetsforlaget, Oslo.

49. Wieme, R. J. 1965. Special problems, p. 94-113. In Agar gel electrophoresis. Elsevier, Amsterdam.

50. Whittler, R. G., S. G. Cary, and R. B. Lindberg. 1956.
Reversion of a pleuropneumonia-like organism to a Corynebacterium during tissue culture passage. J. Gen. Microbiol. 14:763-775.

51. Woese, C. R., J. Maniloff, and L. B. Zablen. 1980. Phylogenetic analysis of the mycoplasmas. Proc. Natl. Acad. Sci. U.S.A. 77:494-498. 